\title{
PENGARUH TEKNIK DAN WAKTU PENGGORENGAN NON VAKUM DAN VAKUM TERHADAP KARAKTERISTIK ORGANOLEPTIK, DAN KIMIA TUMPI-TUMPI TUNA
} (Thunnus sp.)

The Effect of Comparison of Seaweed (Eucheuma cottonii) and Flying Fish (Decapterus spp.) In Production of crackers to Organoleptic, Physical and Chemistry Analysis

\author{
Yulis Adrianti, Tamrin², Kobajashi T. Isamu ${ }^{1}$ \\ 1Jurusan Teknologi Hasil Perikanan, Fakultas Perikanan dan Ilmu Kelautan Universitas Halu Oleo, Kendari, \\ Sulawesi Tenggara, Indonesia \\ 2Jurusan Ilmu dan Teknologi Pangan, Fakultas Pertanian Universitas Halu Oleo, Kendari, Sulawesi Tenggara, \\ Indonesia \\ *Email korespondensi: yuliskendari29@gmail.com (Telp: +6285145234807) \\ Diterima: 29 September/ Disetujui 30 Oktober 2019
}

Cara sitasi: Adrianti Y, Tamrin, Isamu KT. 2019. Pengaruh teknik dan waktu penggorengan non vakum dan vakum terhadap karakteristik organoleptik, dan kimia tumpi-tumpi tuna (Thunnus sp.). Jurnal Fish Protech. 2(2):226-233.

\begin{abstract}
This study aims to determine the effect of non vacuum and vacuum frying techniques and time on the organoleptic and chemical characteristic of tumpi-tumpi tuna (Thunnus sp.). This study used a randomized block design (RBD) with two treatment factors namely the first factor is a frying technique consisting of two levels, namely non vacuum frying techniques and vacuum frying techniques. The second factor is frying time consisting of three levels is (ten minutes), $T_{2}$ (twenty minutes), dan $T_{3}$ (thirty minutes). Organoleptic tests include color, the scent, taste, and texture, while chemical testing uses the method BSN 01-2354.2-2006 include water content, ash content, fat content, and carbohydrate content. Based on the results of the research test, showed that the effect of the technique and the time of non vacuum and vacuum frying on the organoleptic test is color with an average value of 6,46, aroma with an average value of 6,13, taste with an average value of 5,81, and texture with an average value of 5,45 . While the proximate test results that the best water content is in the $V_{1} T_{3}$ treatment with an average value of $3,05 \%$, the best ash content is in the $V_{0} T_{3}$ treatment with an average value of $5,27 \%$, the best fat content is in the $V_{0} T_{3}$ treatment with an average valeu of $14,18 \%$, the best protein content was found in the $V_{1} T_{3}$ treatment with an average value of $13,21 \%$, and carbohyrate content was found in the $V_{0} T_{3}$ treatment with an average value of $65,51 \%$. The conclusion of this research is the effect of the technique and non vacuum and vacuum frying time has a very significant effect, while the interaction has no significant effect on organoleptic values. While the best proximate test result were found in $V_{0} T_{3}$ treatment with an average value of ash content of $5,27 \%$, fat content of $14,18 \%$, carbohydrate $65,51 \%$, and for water and protein content of the best treatment was found in $V_{1} T_{3}$ with successive value according to $3,05 \%$ and $13,21 \%$.
\end{abstract}

Keywords: Tuna fish (Thunnus sp.), non vacuum, vacuum, tumpi-tumpi, organoleptic, dan chemistry

\section{ABSTRAK}

Penelitian ini bertujuan untuk mengetahui pengaruh teknik dan waktu penggorengan non vakum dan vakum terhadap karakteristik organoleptik dan kimia tumpi-tumpi tuna (Thunnus sp.). Metode penelitian ini menggunakan Rancangan Acak Kelompok (RAK) dengan 2 faktor perlakuan yaitu faktor pertama teknik penggorengan yang terdiri dari 2 taraf yaitu teknik penggorengan non vakum $\left(\mathrm{V}_{0}\right)$ dan teknik penggorengan vakum $\left(\mathrm{V}_{1}\right)$. Faktor kedua adalah waktu penggorengan yang terdiri dari 3 taraf yaitu $T_{1}\left(10\right.$ menit), $T_{2}$ (20 menit), dan $T_{3}(30$ menit). Uji organoleptik meliputi warna, aroma, rasa, dan tekstur, sedangkan uji kimia menggunakan metode BSN 01-2354.2-2006 meliputi kadar air, kadar abu, kadar lemak, kadar protein, dan kadar karbohidrat. Berdasarkan hasil penelitian, menunjukkan bahwa pengaruh teknik dan waktu penggorengan non vakum dan vakum terhadap uji organoleptik yaitu warna dengan nilai rata-rata 6,46, aroma dengan nilai rata-rata 6,13, rasa dengan nilai rata-rata 5,81, dan tektur dengan nilai rata-rata 5,45. Sedangkan hasil uji proksimat yaitu kadar air terbaik terdapat pada perlakuan $\mathrm{V}_{1} \mathrm{~T}_{3}$ dengan nilai rata-rata sebesar $3,05 \%$, kandungan kadar abu terbaik terdapat pada perlakuan $\mathrm{V}_{0} \mathrm{~T}_{3}$ dengan nilai rata-rata sebesar $5,27 \%$, kandungan kadar 
lemak terbaik terdapat pada perlakuan $\mathrm{V}_{0} \mathrm{~T}_{3}$ dengan nilai rata-rata sebesar $14,18 \%$, kandungan kadar protein terbaik terdapat pada perlakuan $\mathrm{V}_{1} \mathrm{~T}_{3}$ dengan nilai rata-rata sebesar $13,21 \%$, dan kandungan kadar karbohidrat terbaik terdapat pada perlakuan $\mathrm{V}_{0} \mathrm{~T}_{3}$ dengan nilai rata-rata sebesar $65,51 \%$. Kesimpulan pada penelitian ini adalah pengaruh teknik dan waktu penggorengan non vakum dan vakum berpengaruh sangat nyata, sedangkan pada interaksi berpengaruh tidak nyata pada nilai organoleptik sedangkan hasil uji proksimat terbaik terdapat pada perlakuan $\mathrm{V}_{0} \mathrm{~T}_{3}$ dengan nilai rata-rata kadar abu 5,27\%, kadar lemak $14,18 \%$, karbohidrat $65,51 \%$ dan untuk kadar air, dan kadar protein perlakuan terbaik terdapat pada $\mathrm{V}_{1} \mathrm{~T}_{3}$ dengan nilai berturut-turut $3,05 \%$, dan $13,21 \%$..

Kata kunci: Ikan tuna (Thunnus sp.), non vakum, vakum, tumpi-tumpi, organoleptik, dan kimia

\section{PENDAHULUAN}

Laut Sulawesi merupakan salah satu perairan Indonesia yang menjadi potensi kehidupan ikan tuna. Menurut laporan PPS Kendari (2016), produksi perikanan tangkap seperti ikan tuna, layang/kembung dan cakalang mencapai 19.325 .245 ton. Hasil tangkapan ikan tuna diperoleh dari perairan Selat Makassar, Selat Bone, dan Selat Laut Banda (Statistik PPS Kendari, 2016). Ikan tuna (Thunnus, sp.) merupakan bahan pangan yang bergizi tinggi dengan kandungan protein yang tinggi dan lemak yang rendah. Daging ikan tuna kaya oleh protein dan nutrisi penting lainnya, misalnya asam lemak omega-3, vitamin, dan mineral. Salah satu kelemahan ikan tuna sebagaimana yang juga dimiliki oleh komoditi perikanan lainnya adalah memiliki sifat yang mudah busuk (high perishable food). Oleh karena itu, perlu dilakukan suatu penanganan yang tepat sejak ditangkap meliputi proses pengolahan. Salah satu cara pengolahan ikan tuna yang dapat dilakukan adalah dengan pembuatan tumpi-tumpi.

Ikan tuna merupakan jenis ikan yang paling baik digunakan pada pembuatan tumpi-tumpi karena memiliki struktur daging yang padat, mengandung protein, dan nilai gizi yang tinggi dibandingkan dengan ikan air tawar. Tumpi-tumpi merupakan salah satu jenis makanan tradisional Buton Utara (Butur) berupa bahan baku ikan (daging lumat) yang kekhasannya berbentuk segitiga yang telah dikenal sejak lama secara turun-temurun oleh masyarakat yang berasal dari suku Buton. Makanan tradisional ini terbuat dari campuran daging ikan, telur dan bumbu. Umumnya tumpi-tumpi ini diolah dengan cara digoreng.
Penggorengan merupakan proses pemanasan produk dengan suhu tinggi dan medium minyak goreng sebagai penghantar panas. Ada 2 macam teknik penggorengan, yaitu penggorengan konvensional (non vakum) dan penggorengan dengan vakum (vacuum frying). Penggorengan konvensional (non vakum) dan penggorengan ruang hampa memiliki prinsip yang berbeda. Penggorengan konvensional (non vakum) biasanya menggunakan suhu diatas $100^{\circ} \mathrm{C}$, waktu yang lebih cepat dan dengan tekanan udara $77 \mathrm{cmHg}$. Penggorengan ruang hampa menggunakan suhu yang lebih rendah yaitu $80-100^{\circ} \mathrm{C}$, waktu yang lebih lama dan dengan tekanan udara 60 $76 \mathrm{cmHg}$ (Massinai, 2005). Penggorengan dengan metode vacum akan menghasilkan produk pangan dengan kandungan gizi seperti protein, dan lemak yang tetap terjaga. Sistem penggorengan seperti ini, produk-produk pangan yang rusak dalam penggorengan akan bisa digoreng dengan baik, menghasilkan produk yang kering dan renyah, tanpa mengalami kerusakan nilai gizi dan organoleptik pada warna, rasa, dan aroma yang tidak banyak berubah, kandungan seratnya tinggi, tahan lama meskipun tidak mempergunakan bahan pengawet (Lastriyanto, 2006). Seperti halnya yang terjadi pada penggorengan konvensional/non vakum. Dengan demikian produk yang mengalami kerusakan warna, aroma, rasa, dan nutrisi akibat panas dapat diproses dengan teknologi ini. 


\section{Alat dan Bahan}

\section{METODE PENELITIAN}

Alat yang digunakan dalam penelitian dibagi menjadi 2 yaitu alat untuk pengolahan dan alat untuk analisis. Alat untuk pengolahan meliputi: baskom, pisau, talang, meet grinder (miyako), panci, kompor, wajan, timbangan analitik, stop watch, dan 1 unit alat pengoreng vakum (vacuum fyring). Alat untuk analisis kimia, meliputi: timbangan analitik, pipet tetes, tabung reaksi, gelas ukur, hot-plate, batang pengaduk,

\section{Rancangan Penelitian}

Penelitian ini menggunakan Rancangan Acak Kelompok (RAK) dengan 2 faktor perlakuan, yaitu faktor pertama teknik penggorengan yang terdiri dari 2 taraf yaitu teknik penggorengan non vakum $\left(V_{0}\right)$ dan teknik penggorengan vakum $\left(\mathrm{V}_{1}\right)$. Faktor perlakuan kedua adalah waktu penggorengan yang terdiri dari 3 taraf yaitu $T_{1}$ (10 menit), $T_{2}\left(20\right.$ menit) dan $T_{3}$ (30 menit). Setiap kombinasi perlakuan diulang sebanyak 4 kali sehingga menghasilkan 24 unit percobaan.

\section{Prosedur Penelitian}

Prosedur penelitian ini dapat dilihat pada langkah-langkah sebagai berikut: ikan tuna dibeli dari TPI (Tempat Pelelangan Ikan) bertempat di Kecamatan Sodohoa, Kendari Barat. Setelah itu ikan tuna segar dicuci dari kotoran darah serta dipisahkan bagian yang tidak digunakan seperti sisik, insang dan isi perut dengan menggunakan pisau kemudian dicuci/dibersihkan dengan menggunakan air bersih/mengalir. Daging ikan yang sudah bersih dipotong-potong. Setelah itu dimasukkan dan disusun kedalam wadah perebusan. Kemudian ditambahkan garam, asam, kunyit, dan air. Garam yang ditambahkan 0,5\% dari berat total ikan. Selanutnya, dilakukan pemindangan dengan menggunakan air sebanyak $300 \mathrm{ml}$ selama \pm 30 menit dengan suhu \pm $100^{\circ} \mathrm{C}$. Ketika daging ikan pindang telah masak maka wadah diangkat dan didinginkan pada suhu ruang. spatula, cawan petri, erlenmeyer, desikator, botol pengencer $20 \mathrm{ml}$ dan alat destilasi.

Bahan yang digunakan dalam penelitian ini terdiri atas bahan utama dan bahan pendukung. Bahan utama adalah daging ikan tuna yang diperoleh dari Tempat Pelelangan Ikan (TPI) Sodohoa. Bahan pendukung adalah serei, merica bubuk, garam, asam jawa, bawang merah, bawang putih, telur, cabai rawit, penyedap rasa (MSG), dan minyak goreng. Bahan analisis kimia adalah aquades, alkohol 95\%, $\mathrm{NaOH}, \mathrm{N}$ heksan, $\mathrm{HCl}$, selenium reagentmixture, kertas saring dan larutan standar protein.

Setelah itu dilakukan pemisahan daging ikan dari tulang serta kulitnya sehingga diperoleh daging bersih tanpa tulang dan kulit yang kemudian disuwir-suwir. Selanjutnya diblender sampai halus, kemudian ditimbang sebanyak $76 \%$ yang dilanjutkan dengan bumbu tumpi-tumpi yaitu pertama disiapkan bumbubumbu seperti garam $0,60 \%$, batang serei $1,21 \%$, bawang merah $4,54 \%$, bawang putih $3,39 \%$, merica bubuk $0,60 \%$, kemiri $1,81 \%$, cabai rawit $1,81 \%$, cabai keriting $3,03 \%$, penyedap rasa (MSG) $0,60 \%$, dan telur $6,06 \%$. Semua rempah-rempah dihaluskan dengan menggunakan blender. Kemudian dihomogenkan. Selanjutnya adonan dicetak menjadi bentuk segitiga dengan menggunakan daun pisang. Setelah itu digoreng menggunakan 2 cara yaitu penggorengan vakum dan penggorengan non vakum. pada proses penggorengan non vakum tidak dihidupkan mesin vakumnya sedangkan pada penggorengan vakum dihidupkan mesin vakumnya yang masing-masing menggunakan suhu $100^{\circ} \mathrm{C}$, waktu penggorengan yaitu (10 menit, 20 menit, dan 30 menit) dan tekanan $60-76 \mathrm{cmHg}$.

\section{Analisis Data}

Data hasil penelitian organoleptik dianalisis menggunakan sidik ragam Anova. Jika terdapat pengaruh yang nyata/sangat nyata akan dilakukan uji lanjut menggunakan Duncan DMRT (Duncan Multiple Range Test) dengan taraf kepercayaan $95 \%(\alpha=0,05)$. 


\section{HASIL DAN PEMBAHASAN \\ Uji organoleptik}

Nilai rerata uji organoleptik tiap perlakuan terhadap parameter warna, aroma, rasa dan tekstur dapat dilihat pada Tabel 1, sebagai berikut:

Tabel 1 Nilai rerata tertinggi produk tumpi-tumpi terhadap pengaruh teknik penggorengan non vakum dan penggorengan vakum

\begin{tabular}{ccccc}
\hline Perlakuan & Warna & Aroma & Rasa & Tekstur \\
\hline$V_{0}$ & $5,44^{\mathrm{a}}$ & $5,62^{\mathrm{a}}$ & $4,96^{\mathrm{a}}$ & $3,04^{\mathrm{a}}$ \\
$\mathrm{V}_{1}$ & $7,48^{\mathrm{b}}$ & $6,63^{\mathrm{b}}$ & $6,65^{\mathrm{b}}$ & $7,04^{\mathrm{b}}$ \\
\hline
\end{tabular}

Keterangan: $V_{0}:$ Penggorengan non vakum

$\mathrm{V}_{1}$ : Penggorengan vakum

Nilai rerata hasil analisis ragam uji organoleptik pada produk tumpi-tumpi terhadap pengaruh waktu penggorengan non vakum dan penggorengan vakum dapat dilihat pada Tabel 2 , sebagai berikut:

Tabel 2 Nilai rerata tertinggi produk tumpi-tumpi terhadap pengaruh waktu penggorengan non vakum dan penggorengan vakum

\begin{tabular}{|c|c|c|c|c|}
\hline Perlakuan & Warna & Aroma & Rasa & Tekstur \\
\hline $\mathrm{T}_{1}$ & $\begin{array}{l}\text { 5,86a (Sangat } \\
\text { kekuningan) }\end{array}$ & $\begin{array}{l}\text { 5,84 (Tercium aroma } \\
\text { matang tumpi-tumpi) }\end{array}$ & $\begin{array}{c}5,52^{\mathrm{a}} \text { (Sangat terasa } \\
\text { ikan) }\end{array}$ & 4,32a (Kering) \\
\hline $\mathrm{T}_{2}$ & $\begin{array}{c}6,15^{\mathrm{a}} \text { (Sangat } \\
\text { kekuningan) }\end{array}$ & $\begin{array}{l}6,08 \text { (Tercium aroma } \\
\text { matang tumpi-tumpi) }\end{array}$ & $\begin{array}{c}5,71^{\mathrm{b}} \text { (Sangat terasa } \\
\text { ikan) }\end{array}$ & $\begin{array}{l}5,63^{\mathrm{b}}(\text { Sangat } \\
\text { kering })\end{array}$ \\
\hline $\mathrm{T}_{3}$ & $\begin{array}{l}7,39 \mathrm{~b} \text { (Sangat } \\
\text { kekuningan) }\end{array}$ & $\begin{array}{l}6,47 \text { (Tercium aroma } \\
\text { matang tumpi-tumpi) }\end{array}$ & $\begin{array}{c}6,20^{\mathrm{b}} \text { (Sangat terasa } \\
\text { ikan) }\end{array}$ & $\begin{array}{l}6,41^{c} \text { (Sangat } \\
\text { kering) }\end{array}$ \\
\hline
\end{tabular}

Keterangan : $T_{1}$ : Waktu penggoregan selama 10 menit

$\mathrm{T}_{2}$ : Waktu penggoregan selama 20 menit

$\mathrm{T}_{3}$ : Waktu penggoregan selama 30 menit

Uji Kimia

Adapun nilai rerata perbandingan perlakuan terbaik pada tumpi-tumpi tuna disajikan pada Tabel 3 , sebagai berikut:

Tabel 3. Nilai rerata perbandingan perlakuan terbaik pada penggorengan non vakum dan vakum pada produk tumpi-tumpi tuna

\begin{tabular}{ccccc}
\hline No & Variabel Pengamatan & $\begin{array}{c}\text { Non Vakum } \\
\left(\mathrm{V}_{0} \mathrm{~T}_{3}\right)\end{array}$ & $\begin{array}{c}\text { Perlakuan } \\
\text { Vakum } \\
\left(\mathrm{V}_{1} \mathrm{~T}_{3}\right)\end{array}$ & $\begin{array}{c}\text { SNI 2713.1: } \\
2009\end{array}$ \\
\hline 1. & Kadar Air \% & 4,45 & 3,05 & Maks 12 \\
2. & Kadar Abu \% & 5,27 & 6,64 & Maks 0,2 \\
3. & Kadar Lemak \% & 14,18 & 11,79 & - \\
4. & Kadar Protein \% & 10,56 & 13,21 & Min 5 \\
5. & Kadar karbohidrat \% & 65,51 & 65,29 & - \\
\hline
\end{tabular}

Keterangan: $\mathrm{V}_{0} \mathrm{~T}_{3}$ : Penggorengan Non Vakum selama 30 menit

$V_{1} T_{3}$ : Penggorengan Vakum selama 30 menit 


\section{Uji Organoleptik}

\section{a. Warna}

Warna tumpi-tumpi terbaik masing-masing dihasilkan selama 30 menit pada penggorengan non vakum dan penggorengan vakum dengan skala kesukaan amat sangat berwarna kuning kecoklatan. Hal ini sesuai dengan pernyataan dari Ketaren (2005) yang menyatakan bahwa permukaan lapisan luar akan berwarna kuning kecoklatan akibat penggorengan. Timbulnya warna pada permukaan bahan disebabkan oleh reaksi browning atau reaksi Maillard.

Tingkat intensitas warna ini tergantung dari lama waktu dan suhu menggoreng, juga komposisi kimia pada permukaan luar dari bahan pangan (Yulia et al., 2014). Makanan yang diproses dengan penggorengan vakum akan mempunyai warna yang lebih baik (Auliana, 2001). Perubahan warna terjadi dikarenakan, terjadi kombinasi antara reaksi Maillard dan komponen dalam minyak, yang sejalan dengan penelitian Annisa (2012) yang menyatakan bahwa penggorengan ditujukan untuk meningkatkan karakteristik warna yang merupakan kombinasi dari reaksi Maillard dan komponen volatil yang diserap dari minyak.

\section{b. Aroma}

Aroma tumpi-tumpi yang disukai panelis terdapat pada teknik penggorengan vakum dengan waktu penggorengan selama 30 menit dengan skala amat sangat tercium aroma khas tumpi-tumpi. Hal ini sejalan dengan penelitian Setyaningsih et al., (2010), mengemukakan bahwa adanya dua atau lebih bau dalam produk pangan dapat bercampur untuk saling menguatkan atau saling menutupi. Sehingga bau yang ditimbulkan oleh bahan-bahan penyusun tumpi-tumpi bercampur untuk saling menguatkan dalam membentuk aroma produk yang disukai konsumen.

Menurut Zamora dan Francisco (2005) melaporkan bahwa hasil reaksi antara asam-asam amino dengan gula-gula reduksi akan mengalami reaksi lanjutan, yaitu dehidrasi dan fragmentasi gula serta degradasi stecker menghasilkan komponen volatil yang berperan dalam pembentukan aroma khas produk gorengan.

\section{c. Rasa}

Rasa produk tumpi-tumpi dipengaruhi oleh penambahan bumbu. . Menurut Matti (2013), bumbu merupakan bahan tambahan dalam suatu produk yang berperan memberi rasa khas, meningkatkan rasa, dan menekan rasa tertentu menjadi rasa yang diinginkan serta bisa berfungsi sebagai antimikroba. Hasil uji lanjut menunjukkan perlakuan terbaik yakni pada penggorengan vakum selama 30 menit dengan rata-rata tingkat kesukaan menunjuk pada skala sangat suka. Diduga, penggorengan 30 menit sangat disukai dikarenakan pada penggorengan ini, nutrisi dan rasa dari tumpi-tumpi masih cukup terjaga. Menurut Bambang (1998), rasa merupakan faktor yang paling penting dari produk makanan disamping warna dan aroma. Setiap bahan makanan akan memiliki rasa yang khas sesuai dengan sifat bahan itu sendiri atau adanya zat lain yang ditambahkan pada saat proses pengolahan sehingga rasa aslinya menjadi berkurang atau bahkan lebih baik.

\section{d. Tekstur}

Tekstur tumpi-tumpi dipengaruhi oleh proses spiner selama 2 menit dimana kandungan air yang terdapat dalam ikan digantikan oleh minyak sehingga pada saat proses spiner difungsikan untuk meniriskan minyak yang terkandung dalam produk, kadar air berkurang dan tekstur tumpi-tumpi menjadi renyah. Selain itu juga diakibatkan adanya lapisan crust pada permukaan tumpi-tumpi. Dalam hal ini, kadar air berpengaruh nyata terhadap tekstur tumpi-tumpi yang diujikan dan lebih cenderung disukai panelis pada penggorengan vakum selama 30 menit. Hal ini sejalan dengan pendapat Yayang (2012) yang menyatakan semakin lama penggorengan vakum maka kadar air yang terkandung dalam keripik buah semakin berkurang dan keripik yang dihasilkan semakin renyah. 


\section{Uji Kimia}

\section{a. Kadar Air}

Kadar air tumpi-tumpi dipengaruhi oleh proses spiner selama 2 menit, selama penggorengan non vakum dan vakum berlangsung terjadi proses penghisapan kadar air dari sampel dimana proses tersebut melepaskan kadar air dari pori-pori kemudian digantikan oleh minyak sehingga pada saat proses spiner difungsikan untuk meniriskan minyak yang terkandung dalam produk dan menyebabkan kadar air rendah.

Penyebab dari menurunnya kadar air juga adalah akibat panas dari minyak goreng yang menguapkan sejumlah kadar dari bahan. Peningkatan suhu dan waktu penggorengan akan menurunkan nilai kadar air keripik (Winarti, 2000). Semakin tinggi suhu dan waktu penggorengan vakum maka semakin banyak air yang akan menguap sehingga semakin tebal renyahan yang terbentuk yang secara otomatis akan diisi dengan penyerapan minyak (Block, 1964).

\section{b. Kadar Abu}

Kadar abu tumpi-tumpi meningkat disebabkan oleh penambahan bumbu, proses penggorengan dan suhu yang digunakan. Semakin tinggi suhu yang digunakan maka semakin besar air yang menguap sehingga mengakibatkan semakin besar kadar abu yang dihasilkan (Manurung, 2017).

Menurut Erkan et al. (2010) juga melaporkan bahwa kadar abu beberapa ikan laut meningkat setelah mengalami penggorengan, pemanggangan, dan pengasapan. Kadar abu ikan yang diolah dengan penggorengan lebih tinggi dari pada ikan yang diolah dengan pemanggangan dan pengasapan. Yodkraisri dan Bhat (2012) melaporkan bahwa kadar abu keripik rimpang bunga teratai meningkat setelah mengalami proses penggorengan seiring berkurangnya kadar air dan serat kasar.

\section{c. Kadar Lemak}

Kadar lemak tumpi-tumpi mengalami peningkatan, hal ini disebabkan oleh banyaknya ruang kosong pada produk gorengan yang diisi oleh minyak akibat tingginya suhu dan lamanya waktu penggorengan non vakum (Muchtadi, 2008). Hal ini juga dibuktikan oleh Rosyanti (2000), yang membuktikan bahwa semakin meningkatnya suhu dan lama penggorengan maka kadar lemak keripik akan semakin besar. Selain itu Wijayanti (2011) dalam penelitiannya juga mengemukakan bahwa suhu dan waktu penggorengan berpengaruh nyata terhadap peningkatan kadar lemak. Berdasarkan hasil penelitian Manurung (2011), didapatkan kesimpulan bahwa semakin tinggi suhu dan semakin lama waktu penggorengan maka kadar lemak akan meningkat, hal ini disebabkan oleh banyaknya ruang kosong yang diisi oleh minyak seiring dengan berkurangnya kandungan air dalam bahan.

\section{d. Kadar Protein}

Peningkatan jumlah penggunaan ikan sebanyak $76 \%$ pada pembuatan tumpi-tumpi tuna diduga menjadi faktor utama terhadap tingginya kadar protein produk akhir. Ketersediaan kadar protein dalam produk tumpi-tumpi tuna juga diduga dipengaruhi oleh proses penggorengan. Erkan et al. (2010) menjelaskan bahwa peningkatan kadar protein pada beberapa jenis ikan laut dipengaruhi oleh kadar protein awal ikan, jenis ikan, dan metode pemasakan yang digunakan. Menurut Shofiyatun, 2012 bahwa Kadar protein meningkat dengan bertambahnya suhu dan waktu penggorengan vakum.

\section{e. Karbohidrat}

Karbohidrat dalam bahan pangan merupakan sumber kalori utama bagi mahluk hidup. Karbohidrat memiliki peranan penting dalam menentukan karakteristik bahan makanan, misalnya warna, rasa, tekstur, dan aroma. Kadar karbohidrat dalam bahan makanan dapat mengalami perubahan akibat pengolahan. Teknik penggorengan non vakum dan vakum dalam penelitian ini menggunakan alat penggorengan yang sama yaitu penggorengan vakum namun pada penggorengan non vakum tidak dihidupkan vakumnya sedangkan pada penggorengan vakum dihidupkan vakumnya dengan suhu yang sama $100^{\circ} \mathrm{C}$ kemudian dispiner selama 2 menit. Pada teknik dan penggorengan waktu non vakum dan 
penggorengan vakum tidak memberikan pengaruh nyata terhadap kadar karbohidrat

\section{KESIMPULAN}

Berdasarkan hasil penelitian dari pembahasan, maka dapat disimpulkan sebagai berikut:

1. Terdapat pengaruh teknik dan waktu penggorengan non vakum dan vakum pada tumpi-tumpi tuna terhadap karakteristik organoleptik berpengaruh sangat nyata pada parameter warna, rasa dan tekstur namun pada aroma berpengaruh tidak nyata.

2. Terdapat pengaruh teknik dan waktu penggorengan non vakum dan vakum pada tumpi-tumpi tuna terhadap karakteristik kimia yaitu memberikan pengaruh nyata pada teknik penggorengan non vakum dan vakum disetiap perlakuan $\mathrm{V}_{0} \mathrm{~T}_{3}$, dan $\mathrm{V}_{1} \mathrm{~T}_{3}$ dengan nilai kadar air tertinggi pada $\mathrm{V}_{0} \mathrm{~T}_{3}$, kadar abu tertinggi pada $\mathrm{V}_{1} \mathrm{~T}_{3}$, kadar lemak tertinggi pada $\mathrm{V}_{0} \mathrm{~T}_{3}$, kadar protein tertinggi $\mathrm{V}_{1} \mathrm{~T}_{3}$, dan kadar karbohidrat $\mathrm{V}_{0} \mathrm{~T}_{3}$ berpengaruh tidak nyata pada $\mathrm{V}_{1} \mathrm{~T}_{3}$.

\section{DAFTAR PUSTAKA}

Annisa, R. 2012. Pengaruh Kadar Air Terhadap Tekstur Keripik Pisang Kepok (Musa paradisiaca formatypica). Skripsi. Makassar: Fakultas Pertanian Universitas Hasanuddin

Auliana, R.. 2001. Gizi dan Pengolahan Pangan. Adicita Karya Nusa, Yogyakarta.

Bambang, K., Pudji, H., Wahyu, S., 1998. Pedoman Uji Inderawi Bahan Pangan. Penerbit Pusat Antar Universitas Pangan dan Gizi Universitas Gadjah Mada,Yogyakarta.

Block, Z. 1964. Frying. Di dalam M.A Joslyn dan J.J Heid (ed). Food Process Operation Vol 3. The AVI Publ. Co., Westport.

Erkan, N, Ozden, O, Selcuk, A. 2010. Effect of frying, grilling, and steaming on amino acid composition of marine fishes. Journal of Medicinal Food 13(6):1524-1531..
Ketaren, S. 2005. Pengantar Teknologi Minyak dan Lemak Pangan. UI-Press, Jakarta.

Lastriyanto, A. 2006. Mesin Penggoreng Vakum (Vacuum Frying). Lastrindo Engineering: Malang.

Manurung, O. 2011. Pengaruh Suhu dan Waktu Penggorengan Hampa Terhadap Mutu Keripik Ikan Lemuru (Sardinella longiceps). Skripsi Fakultas Teknologi Pertanian, IPB. Bogor.

Manurung, S. Tumbel, N. 2017. Pengaruh Suhu Dan Waktu Penggorengan Terhadap Mutu Keripik Nenas Penggunakan Penggorengan Vakum. Jurnal Penelitian Teknologi Industri. Vol. 9 No 1.

Massinai, R.. 2005. Pengolahan Sekunder Buahbuahan Menggunakan Vacuum Frying. Balai Pengkajian Tekhnologi Pertanian. Kalimantan Tengah..

Matti, A. 2013. Reformulasi Tumpi Tuna (Thunnus sp.) Sebagai Indigenous Traditional Food Sulselbar Dan Karakterisasi Mutu Selama Penyimpanan Suhu Ruang [Tesis]. Bogor: Sekolah Pascasarjana, Institut Pertanian Bogor.

Muchtadi T.R. 2008. Teknologi Proses Pengolahan Pangan. 3 rd ed. Bogor : Institut Pertanian Bogor.

[PPS Kendari] Pelabuhan Perikanan Samudra Kendari (ID). 2016. Buku Profile (Statistik) PPS Kendari. Direktorat Jendral Kementrian Kelautan Perikanan (KKP). 1(1): 13-19.

Rosyanti, R.S. 2000. Optimasi suhu dan waktu penggorengan hampa jamur tiram (Pleurotusostreatus). Skripisi Fakultas Teknologi Pertanian, IPB, Bogor

Setyaningsih D, Apriyantono A, Sari M.P. 2010. Analisis Sensori untuk Industri Pangan dan Agro. Bogor: IPB Press

Shofiyatun, N.F. 2012. Optimasi Proses Penggorengan Vakum (Vacuum Frying) Keripik Daging Sapi. Skripsi Fakultas Teknologi Pertanian. IPB. Bogor.

Wijayanti, R. 2011. Kajian Rekayasa Proses Penggorengan Hampa dan Kalayakan Usaha Produksi Keripik Pisang [tesis]. Bogor: Sekolah Pascasarjana, Institut Pertanian Bogor. 
ISSN : 2621 - 1475

Winarno, F.G. 2008. Kimia pangan dan gizi. Edisi terbaru. Bogor: M-Brio Press.

Winarti, 2000. Pengaruh suhu dan waktu penggorengan hampa terhadap mutu keripik manggalndramayu (Mangifera indica L.). Skripisi Fakultas Teknologi Pertanian, IPB, Bogor.

Yayang, A.S. 2012. Pembuatan Keripik Pepaya Menggunakan Metode Penggorengan
Vakuum dengan Variabel Suhu dan Waktu. Tugas Akhir Fakultas Teknik. UNDIP. Semarang..

Zamora R, Hidalgo ZJ. 2005. Coordinate contribution of lipid oxidation and Maillard reaction to the nonenzymatic food browning. Critical Reviews in Food Science and Nutrition. 45(1): 49-59. 